\title{
Characterisation of anaerobic curved rods (Mobiluncus spp.) isolated from the urogenital tract
}

\author{
A. VETERE,* S. P. BORRIELLO, E. FONTAINE, P. J. REED and D. TAYLOR-ROBINSON†
}

\begin{abstract}
Divisions of Sexually Transmitted Diseases and Communicable Diseases, Clinical Research Centre, Watford Road, Harrow, Middlesex HA1 3UJ
\end{abstract}

\begin{abstract}
Summary. Thirty-two strains of anaerobic curved rods isolated from vaginal secretions and one isolated from seminal fluid were examined. Growth of all strains on solid media was superior to growth in liquid media, and at $37^{\circ} \mathrm{C}$ they grew both anaerobically and in $\mathrm{O}_{2} 5 \%$ in $\mathrm{N}_{2}$; they also grew anaerobically at $33^{\circ} \mathrm{C}$ but not at $42^{\circ} \mathrm{C}$. No growth factors were identified, but strains grew more profusely at $p \mathrm{H}$ values above 5.0. The strains were screened in 80 biochemical tests, and for their susceptibility to 30 different antimicrobial agents. Most of the tests did not differentiate between the strains, but they were divided into four groups on the basis of cell morphology, metronidazole susceptibility, $\beta$-galactosidase activity and arginine and hippurate hydrolysis. Group 1 consisted of 19 strains conforming to the species $M$. curtisi; group 2 consisted of five strains conforming to the species $M$. mulieris; group 3 consisted of five strains that resembled $M$. curtisi morphologically, and group 4 consisted of four strains that resembled $M$. mulieris morphologically, but the strains in the latter two groups reacted differently in at least one of the three major differential biochemical tests. Of three strains of $M$. curtisi and three of $M$. mulieris chosen at random, one of $M$. mulieris had a SDS-PAGE and fast-protein liquid chromatography protein profile indistinguishable from that of $M$. curtisi. We conclude that further efforts are required to clarify the taxonomic status of the genus Mobiluncus.
\end{abstract}

\section{Introduction}

There has been much interest recently in anaerobic, curved, motile gram-negative bacteria present as components of the vaginal flora, especially as carriage appears to be associated with bacterial vaginosis (Durieux and Dublanchet, 1980; Skarin and Mårdh, 1982; Sprott et al., 1982, 1983, 1984; Phillips and Taylor, 1982; Blackwell et al., 1983; Spiegel et al., 1980, 1983). These anaerobic curved rods have been given the genus name Mobiluncus, and two species, $M$. curtisi (curtisii) and $M$. mulieris have been proposed (Spiegel and Roberts, 1984). The two species can be differentiated by cell morphology and biochemical reactions, the most useful of these- $\beta$-galactosidase activity, arginine and hippurate hydrolysis and metronidazole susceptibility-having been proposed for differentiation (Nord et al., 1984). M. curtisi organisms, referred to as "short forms" (SF) are considered to be $1-2 \mu \mathrm{m}$

Received 2 Jun. 1986; accepted 12 Aug. 1986.

* Visiting worker from Clinica Medica Generale e Terapia Medica III, Universita Degli Studi di Roma, Italy.

$\uparrow$ Correspondence should be sent to D. Taylor-Robinson. long, gram-variable, comma-shaped, resistant to metronidazole, and give positive results in all these differential biochemical tests. In contrast, $M$. mulieris organisms, referred to as "long forms" (LF), are considered to be 3-4 $\mu \mathrm{m}$ long, gramnegative, curved, sensitive to metronidazole, and give negative results in the three biochemical reactions. However, careful analysis of the literature shows that not all strains conform to these guidelines and we refer later to typical short forms (TSF) and typical long forms (TLF) for those that do, and atypical short forms (ASF) and atypical long forms (ALF) for those that do not. An additional problem is the fastidious nature of the organisms which complicates their isolation and subsequent cultivation. The purpose of this study was to investigate extensively the biochemical reactions of Mobiluncus species, to validate and better define any differential characteristics, to determine their antimicrobial susceptibilities with a view to identifying agents that might prove useful in the development of a selective medium, and to try to find cultural conditions or agents that would enhance growth and so facilitate their isolation. 


\section{Materials and methods}

\section{Bacterial strains}

Strains from various geographical sources (table I) were from women with bacterial vaginosis, except strain 32.T which was isolated from the seminal fluid of an infertile male. The strains are designated in the table as "short gram-variable" and "long gram-negative" according to the presumptive descriptions provided by the senders. They were subcultured every 5-7 days on Columbia blood agar (CBA) (Difco) and incubated anaerobically at $37^{\circ} \mathrm{C}$.

\section{Media}

The growth of strains was tested in peptone-yeastglucose broth and in the following broths and on their respective agar media: Brain Heart Infusion (BHI; Difco), Brucella (Oxoid) and Wilkins-Chalgren (Oxoid). The agar media were supplemented with horse blood $5 \%$.

\section{Agents used to enhance growth}

Arginine-free base (Sigma) $2 \%$, sodium hippurate (Sigma) $2 \%$, sodium salts of formate and fumarate $0.3 \%$, bovine serum $2.5 \%$ and campylobacter growth supplement-FBP (Oxoid) were added as single supplements to $\mathrm{BHI}$ broth to test for growth enhancement.

\section{Incubation conditions}

The strains were seeded on to CBA and the cultures incubated at $37^{\circ} \mathrm{C}$ in the following atmospheres : anaerobic $\left(\mathrm{N}_{2} 80 \%, \mathrm{H}_{2} 10 \%, \mathrm{CO}_{2} 10 \%\right)$, aerobic, $\mathrm{CO}_{2} 5 \%$ in air, $\mathrm{O}_{2} 5 \%$ in $\mathrm{N}_{2}$ and in a candle-jar. Cultures were also incubated in anaerobic conditions at $33^{\circ} \mathrm{C}$ and $42^{\circ} \mathrm{C}$. All plate cultures were examined daily up to 10 days for bacterial growth.

\section{Morphology}

After various periods of anaerobic incubation on CBA, the strains were examined for colony morphology. Cell morphology was observed after staining by Gram's method.

\section{Bacterial suspensions}

A bacterial suspension equivalent to McFarland's tube no. $3\left(c .1 \times 10^{7} \mathrm{cfu} / \mathrm{ml}\right)$ was prepared by harvesting the growth on two CBA plates with cotton-wool swabs and expressing them in $3 \mathrm{ml}$ of BHI broth. For a suspension equivalent to McFarland's tube no. $5\left(c .1 \times 10^{9} \mathrm{cfu} / \mathrm{ml}\right)$, the growth from ten plates was expressed in $2 \mathrm{ml}$ of medium.

\section{Effect of pH on growth}

Suspensions of four TSF (M. curtisi) (A225, 69.10, A345, 2199) and four TLF (M. mulieris) (A201, A226, A229, 999.V) (McFarland's tube no. 5) were diluted in a series of eight ten-fold steps. A 30- $\mu$ l sample of each dilution was inoculated on to CBA, unbuffered and buffered with mono- and di-basic sodium sulphate to $p \mathrm{H}$ $7 \cdot 2$, after which the media were incubated anaerobically at $37^{\circ} \mathrm{C}$. The size and the numbers of colonies were estimated $48 \mathrm{~h}$ and $72 \mathrm{~h}$ later. Furthermore, the growth of strains in $\mathrm{BHI}$ broth, adjusted to $p \mathrm{H}$ values over a range from 4 to 8 (half unit intervals), was assessed.

\section{Biochemical characterisation}

Tests for catalase, oxidase and $\beta$-D-galactosidase (ONPG) activity, arginine, hippurate and starch hydrolysis and nitrate reduction were performed as described by Cowan (1974). For these, bacterial suspensions equivalent to McFarland's tube no. 3 were used. All tests were repeated on three separate occasions. Five different test kits (API Laboratory Ltd), namely API-AN1, AN2, AN3 (not commercially available), 20A and ZYM, containing a total of 73 different tests, were used. Fermentation reactions were evaluated with the APIAN3 test strips for L-arabinose, arbutine, cellobiose, fructose, galactose, glucose, glycerol, lactose, mannitol, melibiose, $\alpha$-methyl-D-glucoside, $\alpha$-methyl-D-mannoside, D-ribose, trehalose and D-xylose, and with the API 20A kit for maltose, mannose, melezitose, raffinose, rhamnose, salicin, sorbitol and sucrose. Aesculin hydrolysis, gelatin liquefaction, indole production and urease tests were performed with API 20A and tetrathionate reduction with API-AN3. Another 45 enzyme activities were assayed with the API ZYM and the API-AN1 and AN2 test strips.

\section{Analysis of cell proteins}

The cell proteins of three TSF (M. curtisi) (A225, 69.10, 2199) and TLF (M. mulieris) (A99, A201, A229) were analysed by SDS-polyacrylamide gel electrophoresis (PAGE), as described by Baron et al. (1984), and by fast protein liquid chromatography (FPLC), as described recently (Borriello et al., 1985, 1986).

\section{Antimicrobial susceptibility}

Susceptibility to antimicrobials was determined by the disk-diffusion method. CBA was seeded with $100 \mu \mathrm{l}$ of bacterial suspension (equivalent to McFarland's tube no. 3 ) and the plate culture was incubated anaerobically at $37^{\circ} \mathrm{C}$ for 5 days. Susceptibility to the antiseptic Irgasan (Ciba-Geigy) at a concentration of $100 \mu \mathrm{g} / \mathrm{ml}$ was assayed by the agar dilution method with the same medium.

\section{Motility}

This was determined by the hanging-drop technique. 


\section{Gas liquid chromatography (GLC)}

For analysis by GLC, the strains were grown in chopped-meat-carbohydrate broth (Southern Group Laboratories) for one week anaerobically. The volatile and methylated fatty acids were extracted and detected as described elsewhere (Holdeman et al., 1977).

\section{Results}

\section{Colony morphology}

All strains produced colonies that were small (1-2 $\mathrm{mm}$ in diameter), slightly convex, entire and transparent. The colony morphology of the SF and LF of Mobiluncus, whether typical or atypical forms, was indistinguishable, but $\beta$-haemolysis developed around colonies of LF more often than around those of SF.

\section{Growth on different media}

The rate of development or the size of colonies of the various strains of Mobiluncus species was not different on any of the solid media. Growth in liquid media was always poorer and slower than on solid media. None of the potential growth factors that were added had any significant effect on growth in either liquid or solid media.

\section{Growth in different atmospheric conditions}

All strains grew anaerobically at $33^{\circ} \mathrm{C}$ and $37^{\circ} \mathrm{C}$, but not at $42^{\circ} \mathrm{C}$. No growth occurred on CBA incubated in aerobic conditions, or in a candle-jar even after repeated subculture for 4 months that might have induced aerotolerance. All strains produced very small transparent colonies after incubation for 10 days in $\mathrm{O}_{2} 5 \%$ in $\mathrm{N}_{2}$.

\section{Influence of $p H$}

The number or size of colonies produced by the various strains of SF and LF was not different on buffered or unbuffered CBA after incubation for either $48 \mathrm{~h}$ or $72 \mathrm{~h}$. Only scanty growth occurred in broth media at $p \mathrm{H} \mathrm{4,4.5}$ and 5 ; more profuse growth occurred at all higher $p \mathrm{H}$ values tested.

\section{Biochemical differentiation}

On the basis of morphology in Gram's stains, metronidazole susceptibility, $\beta$-galactosidase activity and arginine and hippurate hydrolysis, the strains were divided into four groups:
"Typical" short forms (TSF) were gram-variable, comma-shaped rods, 1-2 $\mu \mathrm{m}$ long. They hydrolysed arginine and hippurate, exhibited $\beta$-galactosidase activity and were metronidazole resistant. These organisms are classed as $M$. curtisi.

"Typical" long forms (TLF) were gram-negative, curved rods with tapered ends, about 3-4 $\mu \mathrm{m}$ long. They did not hydrolyse arginine or hippurate or exhibit $\beta$-galactosidase activity and were metronidazole sensitive. These organisms are classed as $M$. mulieris.

"Atypical" short forms (ASF) were the same as the TSF morphologically, but gave different reactions in one or more of the three major differential biochemical tests.

"Atypical" long forms ( $A L F$ ) were the same as the TLF morphologically, but gave different reactions in metronidazole susceptibility, or in the three major differential biochemical tests, or both.

According to the criteria above, of 20 strains received as short forms (table I), 16 were TSF and four (A275, A277, A345, MT72.10) were ASF; of 13 strains received as long forms (table I), five (A99, A200, A201, A226, A229) were TLF, four (A198, A221, A227, 999.V) were ALF, three (0.63, 99.12, 2313) were TSF and one (A199) was an ASF. This yielded a total of 19 TSF, five TLF, five ASF and four ALF (table II). Of the five ASF, two (A275, A345) were negative in tests for ONPG activity, two (A199, MT72.10) did not hydrolyse hippurate and one (A277) did not hydrolyse arginine (table II). Of the four ALF, one (999.V) hydrolysed hippurate, one (A198) was resistant to metronidazole but gave positive reactions in the other three major differential tests, one (A227) was resistant to metronidazole and gave negative reactions in the three major differential tests, and one (A221) was metronidazole resistant but gave positive reactions in tests for ONPG activity and arginine hydrolysis (table II).

Fermentation reactions. The results are shown in table III. All strains fermented ribose and xylose, but none fermented arbutine, lactose, maltose, mannitol, mannose, melibiose, raffinose, rhamnose, salicin, sorbitol or sucrose. All the LF (typical and atypical) fermented arabinose, fructose, galactose and glucose, but only some of the short forms did so. The majority $(80 \%)$ of the TLF and $50 \%$ and $25 \%$, respectively, of the ALF gave positive results in tests for $\alpha$-methyl-D-glucoside and trehalose, whereas all the short forms gave negative reactions. Moreover, none of the SF fermented $a$-methyl-Dmannoside or cellobiose, but some of the LF did.

Enzymic reactions. The results are shown in table 
Table I. Source of strains of Mobiluncus spp.

Bacterial strain* Source

Short, gram variable

A98, A223, A225, A228, A274, A275, National Collection of Type Cultures, London

A276, A277

69.10, 101.8, F81, F82, MT31.6, MT72.10

Department of Microbiology, St Thomas's Hospital

A25, A345, A408

2199,3405

Department of Bacteriology, University of Uppsala, Sweden

32. $\mathrm{T} \dagger$

Department of Medical Microbiology, University of Lund, Sweden

St Bartholomew's Hospital, London

Long, gram negative

A99, A198, A199‡, A200, A201, A221,

A226, A227, A229

$99.12 \ddagger$

National Collection of Type Cultures, London

$0.63 \ddagger$

Department of Microbiology, St Thomas's Hospital Medical School, London

999.V, 2313‡

Department of Bacteriology, University of Uppsala, Sweden

Department of Medical Microbiology, University of Lund, Sweden

* Presumptive designation as provided by sender; subsequent classification of all strains is presented under "biochemical differentiation" in Results section.

$\dagger$ Isolated from seminal fluid.

$\$$ Further examination showed these to be short forms.

IV. All strains gave positive results for $\mathrm{C}_{8}$ esterase lipase, $\alpha$-glucosidase, leucine aminopeptidase and the following arylamidases: arginine, proline, alanine-phenylalanine-proline, phenylalanine-arginine and proline-arginine, whereas all strains gave negative reactions for cystine arylamidase, $\beta$-Dfucosidase, phospho- $\beta$-galactosidase, $\beta$-glucuronidase, $C_{14}$ lipase, naphthol-AS-B1-phosphohydrolase and trypsin. For the other reactions, no difference between any of the groups was evident except for the test with $\alpha$-galactosidase, in which almost all the short forms gave positive reactions and all but one of the long forms gave negative reactions.

Additional biochemical tests. All strains gave positive results in tests for nitrate and tetrathionate reduction and for starch hydrolysis, but negative results in tests for aesculin hydrolysis, catalase and

Table II. The grouping of Mobiluncus strains according to the biochemical tests recommended by the working group on diagnostic criteria for anaerobic curved rods (Nord et al., 1984)

\begin{tabular}{lllcccc}
\hline Group (number) & Strain no. & $\begin{array}{c}\text { Gram } \\
\text { staining } \\
\text { reaction }\end{array}$ & $\begin{array}{c}\text { Metronidazole } \\
\text { susceptibility }\end{array}$ & $\begin{array}{c}\beta \text {-Galactosidase } \\
\text { (ONPG) activity }\end{array}$ & $\begin{array}{c}\text { Arginine } \\
\text { hydrolysis }\end{array}$ & $\begin{array}{c}\text { Hippurate } \\
\text { hydrolysis }\end{array}$ \\
\hline Typical short forms (19) & & Variable & Resistant & + & + & + \\
Atypical short forms (5) & A275, A345 & Variable & Resistant & - & + & + \\
& A199, MT72.10 & Variable & Resistant & + & + & - \\
Atypical long forms (4) & A277 & Variable & Resistant & + & - & + \\
& A198 & Negative & Sensitive & - & - & + \\
& A227 & Negative & Resistant & + & + & + \\
Typical long forms (5) & A221 & Negative & Resistant & - & - & - \\
& & Negative & Resistant & + & + & - \\
\hline
\end{tabular}


Table III. Fermentation reactions of strains of Mobiluncus spp.

\begin{tabular}{|c|c|c|c|c|}
\hline \multirow[b]{2}{*}{ Carbohydrate tested } & \multicolumn{4}{|c|}{ Percentage of indicated strains* positive in fermentation test } \\
\hline & TSF (19) & TLF (5) & ASF (5) & ALF (4) \\
\hline D-Ribose, D-Xylose & 100 & 100 & 100 & 100 \\
\hline L-Arabinose & 95 & 100 & 100 & 100 \\
\hline Galactose & 42 & 100 & 80 & 100 \\
\hline Fructose & 53 & 100 & 40 & 100 \\
\hline Glucose & 21 & 100 & 60 & 100 \\
\hline$\alpha$-Methyl-D-glucoside & 0 & 80 & 0 & 50 \\
\hline Trehalose & 0 & 80 & 0 & 25 \\
\hline$\alpha$-Methyl-D-mannoside & 0 & 20 & 0 & 50 \\
\hline Cellobiose & 0 & 20 & 0 & 25 \\
\hline Glycerol & 0 & 20 & 0 & 25 \\
\hline Melezitose & 5 & 20 & 0 & 0 \\
\hline $\begin{array}{l}\text { Arbutine, lactose, maltose, } \\
\text { mannitol, mannose, melibiose, } \\
\text { raffinose, rhamnose, salicin, } \\
\text { sorbitol, sucrose }\end{array}$ & 0 & 0 & 0 & 0 \\
\hline
\end{tabular}

* Numbers in parentheses indicate numbers of strains tested.

oxidase activity, gelatin liquefaction, indole production and urease activity (table V). Furthermore, all strains showed a peculiar "corkscrew" motility.

\section{Cell proteins}

The three TSF (A225, 69.10, 2199) gave identical protein profiles by both SDS-PAGE analysis (fig. 1) and FPLC (fig. 2). Two of the three TLF strains (A201, A229) yielded profiles that were different from those of the SF strains by both SDS-PAGE and FPLC. The protein profiles of these two TLF were identical in FPLC and differed by only one major protein band on SDS-PAGE analysis. The remaining strain (A99), regarded as a TLF, had a protein profile indistinguishable from that of a TSF by both methods of analysis.

\section{GLC profile}

All strains had similar fatty-acid patterns representing production of large amounts of succinic acid and less of acetic and lactic acids.

\section{Susceptibility to antimicrobials}

The results of susceptibility tests are shown in table VI. However, details of susceptibility to metronidazole, which is an important differential characteristic, are shown in table II. It may be seen that several of the LF are atypical in being resistant to metronidazole. All strains were sensitive to the antiseptic Irgasan, bile salts and thallous acetate, but resistant to the three dyes tested (table VI).

\section{Discussion}

The major problem encountered in attempting to elucidate the pathogenic role of the Mobiluncus species in bacterial vaginosis is the difficulty of isolating, culturing and recognising the organisms. They are fastidious and the development on primary isolation of only small colonies makes them difficult to recognise in cultures of vaginal specimens. This is in keeping with the observations of others that the isolation of these organisms is tedious (Durieux and Dublanchet, 1980), several weeks sometimes being required to obtain a pure culture (Thomason et al., 1984). We tried to determine whether there were particular cultural conditions or agents that would enhance growth but no differences were observed in the growth of the strains on various solid and liquid media, although it was clear that they preferred growth on the former and only under anaerobic conditions or in $\mathrm{O}_{2} 5 \%$ in $\mathrm{N}_{2}$. These findings are in agreement with those of other workers (Sprott et al. 1984) but differ in part from those reported by Holst et al. (1982) who found that only the metronidazole-resistant SF grew in microaerophilic conditions. We did not find any correlation between metronidazole-resistant strains and their tolerance of oxygen, metronidazole-sensitive strains growing equally as well as the resistant ones in $\mathrm{O}_{2} 5 \%$. We found no improvement in growth of 
Table IV. Enzyme profiles of strains of Mobiluncus spp.

Percentage of indicated strains* reactive in test

\section{Enzyme tested}

TSF (19)

TLF (5)

ASF (5)

ALF (4)

$\mathrm{C}_{8}$ esterase lipase

$\alpha$-glucosidase

Arginine arylamidase

Leucine aminopeptidase

Proline arylamidase

Alanine-phenylalanine-proline arylamidase

Phenylalanine-arginine arylamidase

Proline-arginine arylamidase

Hydroxyproline arylamidase

Esterase $\mathrm{C}_{4}$, leucine arylamidase

Lysylalanine arylamidase

Aspartic arylamidase

Ornithine arylamidase

Phenylalanine arylamidase

Serine arylamidase

Histidyl-phenylalanine arylamidase

Leucyl-glycine-arylamidase

Glutamine arylamidase

Histidine arylamidase

$\beta$-galactosidase (ONPG)

$\alpha$-galactosidase

Acid phosphatase

Glutamyl-histidine arylamidase

Lipase $\mathrm{C}_{10}$

Valine arylamidase

$\alpha$-fucosidase

$\alpha$-mannosidase

$\alpha$-glutamyl-transpeptidase

Alkaline phosphatase

$\beta$-glucuronidase

Glutamyl-glutamic arylamidase

$\mathrm{N}$-Acetyl- $\beta$-glucosaminidase

$\beta$-glucosidase, pyrrolidonic arylamidase

$L$-arabinosidase, $\beta$-mannosidase

Cystine arylamidase

$\beta$-D-fucosidase

Phospho- $\beta$-galactosidase

$\beta$-glucuronidase

$\mathrm{C}_{14}$ lipase

Naphthol-AS-Bl-phosphohydrolase

Trypsin, chymotrypsin
100

100

100

100

$\begin{array}{rr}95 & 100 \\ 89 & 100 \\ 89 & 100 \\ 95 & 80 \\ 95 & 80 \\ 100 & 100 \\ 95 & 80 \\ 84 & 100 \\ 100 & 80 \\ 68 & 100 \\ 89 & 80 \\ 100 & 0 \\ 89 & 0 \\ 37 & 60 \\ 26 & 20 \\ 16 & 20 \\ 14 & 33 \\ 0 & 20 \\ 16 & 0 \\ 10 & 0 \\ 0 & 0 \\ 0 & 0 \\ 16 & 0 \\ 10 & 0 \\ 10 & 0 \\ 5 & 0\end{array}$

0
0

$\begin{array}{rr}100 & 100 \\ 100 & 100 \\ 100 & 100 \\ 100 & 100 \\ 100 & 100 \\ 100 & 75 \\ 100 & 100 \\ 100 & 75 \\ 100 & 75 \\ 80 & 100 \\ 100 & 75 \\ 60 & 50 \\ 80 & 25 \\ 40 & 50 \\ 40 & 50 \\ 40 & 25 \\ 0 & 0 \\ 0 & 25 \\ 20 & 0 \\ 20 & 0 \\ 20 & 0 \\ 20 & 0 \\ 0 & 0 \\ 0 & 0 \\ 0 & 0 \\ 0 & 0\end{array}$

0

100

100

100

100
75

100

75

75

50

50

25

0

25
0

0

0

0
0

0
0
100
75

25
50

\}

* Numbers in parentheses indicate numbers of strains tested.

the organisms at a particular $p \mathrm{H}$ value or on buffered agar, but noticed that they were tolerant of $p \mathrm{H} \mathrm{8,} \mathrm{the} \mathrm{maximum} \mathrm{value} \mathrm{tested,} \mathrm{and} \mathrm{that} \mathrm{their}$ growth was sparse at $p \mathrm{H}$ values $<6$. These findings might explain the reported low isolation rate of Mobiluncus species from the vaginas of healthy women (Spiegel et al., 1980, 1983; Skarin and Mårdh, 1982; Blackwell et al., 1983) because the normal vaginal environment has a $p \mathrm{H}$ value of 4.5 or less. The increased vaginal $p \mathrm{H}$ in bacterial vaginosis, probably due to diminished numbers of lactobacilli, may facilitate the growth of organisms of the Mobiluncus species.

Organisms within the genus Mobiluncus are divided into two species on the basis of their cell morphology, reaction in Gram's stain, metronidazole susceptibility, arginine and hippurate hydrolysis, and $\beta$-galactosidase reactions (Nord et al., 1984). SDS-PAGE, DNA-DNA hybridisation and serological studies (Baron et al., 1984; Moi and 
Table V. Biochemical reactions of strains of Mobiluncus spp.

\begin{tabular}{|c|c|c|c|c|}
\hline \multirow[b]{2}{*}{ Activity tested } & \multicolumn{4}{|c|}{ Percentage of indicated strains ${ }^{*}$ positive in test } \\
\hline & TSF (19) & TLF (5) & ASF (5) & ALF (4) \\
\hline Nitrate and tetrathionate reduction & 100 & 100 & 100 & 100 \\
\hline Starch hydrolysis & 100 & 100 & 100 & 100 \\
\hline Arginine hydrolysis & 100 & 0 & 80 & 75 \\
\hline Hippurate hydrolysis & 100 & 0 & 60 & 50 \\
\hline$\beta$-galactosidase (ONPG) & 100 & 0 & 60 & 50 \\
\hline $\left.\begin{array}{l}\text { Aesculin hydrolysis, catalase, oxidase, gelatin } \\
\text { liquefaction, indole production, urease }\end{array}\right\}$ & 0 & 0 & 0 & 0 \\
\hline
\end{tabular}

* Numbers in parentheses indicate numbers of strains tested.

Danielsson, 1984; Taylor and Owen, 1984) also differentiate these organisms into two definite species. However, we found that four of the 13 strains received as LF were SF and, furthermore, not all the strains conformed to the proposed criteria for $M$. curtisi (our TSF) or $M$. mulieris (our
TLF). Our findings were repeatable in tests undertaken on at least three different occasions and are in agreement with those of Påhlson et al. (1984) who found four of $15 \mathrm{SF}$ to be atypical in that they did not hydrolyse hippurate or have ONPG activity and did not react with antisera to $M$. curtisi or $M$.

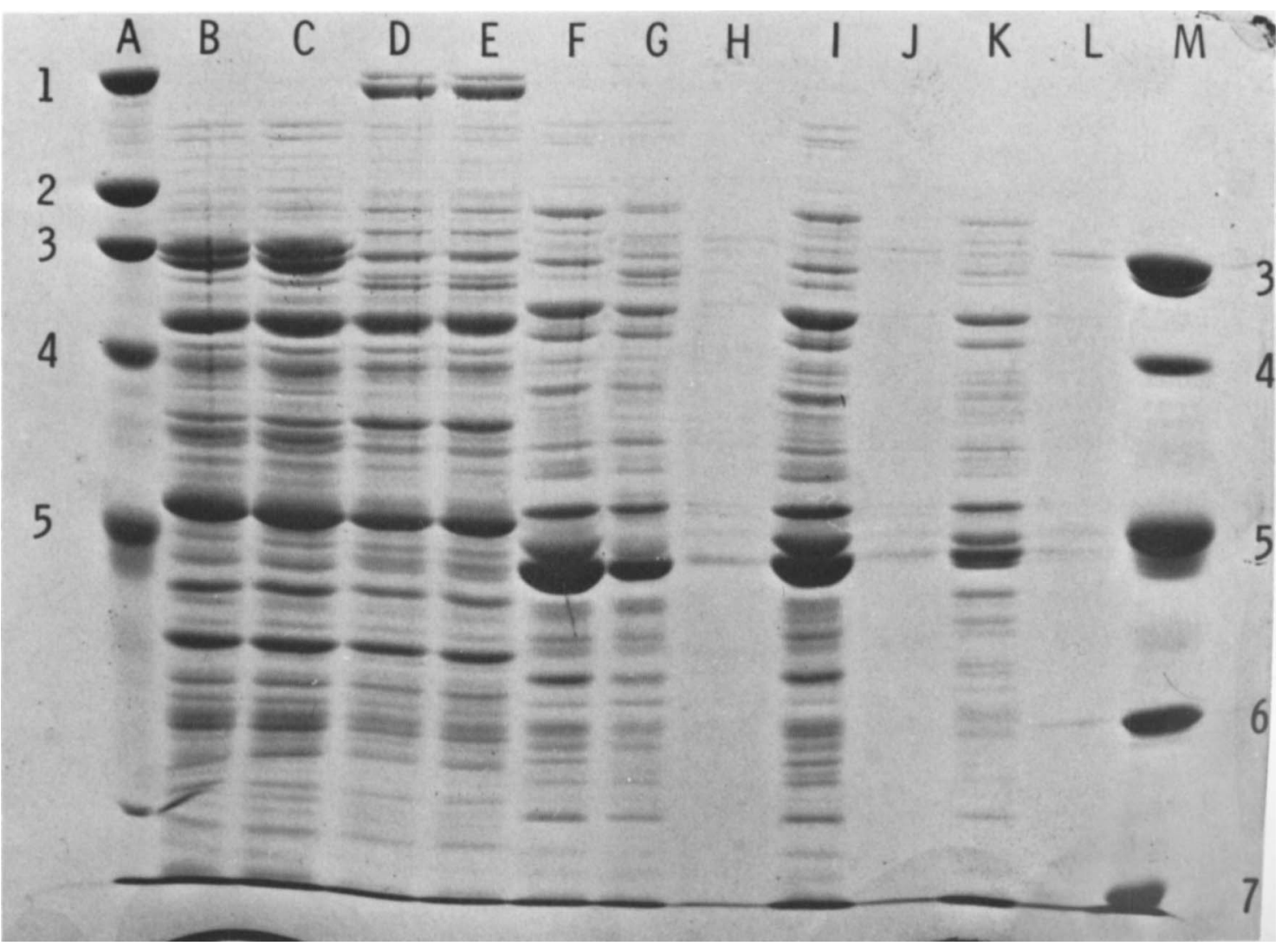

Fig. 1. SDS-PAGE patterns of major cell proteins of Mobiluncus spp. Tracks A and $\mathbf{M}$ contain protein standards of known mol. wts $\left(10^{3}\right): 1-200,2-116 \cdot 25,3-92 \cdot 5,4-66 \cdot 2,5-45,6-31,7-21$. Tracks B and C refer to strain A201 (TLF), tracks D and E to strain A229 (TFL), track F to strain 69.10 (TSF), track G to strain A99 (TLF showing a TSF profile); tracks H, J and L are blank, track I refers to strain A225 (TSF) and track K to strain 2199 (TSF). 
Table VI. Antimicrobial susceptibility of strains of Mobiluncus spp.

Antimicrobial to which strains were sensitive or resistant at indicated quantity (disk)

\begin{tabular}{lclr}
\hline Sensitive & & & \\
Bacitracin & $10 \mathrm{I} . \mathrm{U}$. & Streptomycin & $5 \mu \mathrm{g}$ \\
Cefoxitin & $30 \mu \mathrm{g}$ & Teicoplanin & $30 \mu \mathrm{g}$ \\
Clindamycin & $2 \mu \mathrm{g}$ & Tetracycline & $30 \mu \mathrm{g}$ \\
Ciprofloxacin & $5 \mu \mathrm{g}$ & Vancomycin & $5 \mu \mathrm{g}$ \\
Erythromycin & $5 \mu \mathrm{g}$ & Nitrofurantoin & $100 \mu \mathrm{g}$ \\
Gentamicin & $10 \mu \mathrm{g}$ & Thallous acetate & $500 \mu \mathrm{g}$ \\
Kanamycin & $30 \mu \mathrm{g}$ & Sodium taurocholate & $2 \cdot 5 \mu \mathrm{g}$ \\
Minocycline & $10 \mu \mathrm{g}$ & Sodium deoxycholate & $0.5 \mu \mathrm{g}$ \\
Penicillin & $1.5 \mu \mathrm{g}$ & Irgasan & $100 \mu \mathrm{g} / \mathrm{ml}$ \\
& & & \\
Resistant & & & $10 \mu \mathrm{g}$ \\
Aztreonam & $50 \mu \mathrm{g}$ & Fusidic acid & $10 \mu \mathrm{g}$ \\
Colistin sulphate & $10 \mu \mathrm{g}$ & Neomicin & $0.001 \mu \mathrm{g}$ \\
Nalidixic acid & $10 \mu \mathrm{g}$ & Brilliant green & $0.001 \mu \mathrm{g}$ \\
Polymixin B & $300 \mu \mathrm{g}$ & Methyl violet & $0.001 \mu \mathrm{g}$ \\
Sulphafurazole & $100 \mu \mathrm{g}$ & Victoria blue & \\
Sulphamethoxazole & $2 \cdot 5 \mu \mathrm{g}$ & & \\
Trimethoprim & $1100 \mu \mathrm{g}$ & & \\
& & & \\
\hline
\end{tabular}

* Concentration in agar.

\section{a) Mobiluncus curtisi}

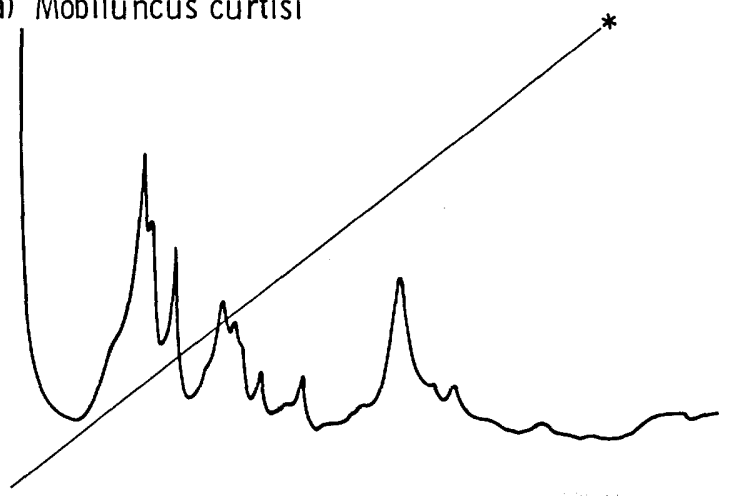

b) Mobiluncus mulieris

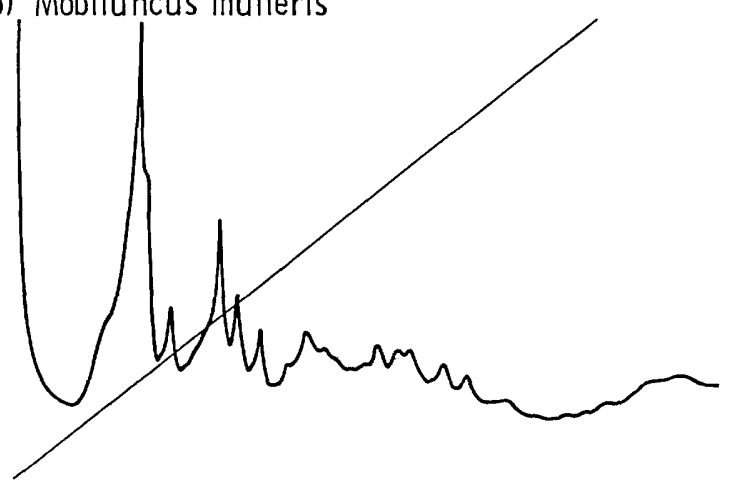

Fig. 2. Fast-protein liquid chromatography profile of cell proteins of Mobiluncus spp. a. Profile of strains 69.10 (TSF), A225 (TSF), 2199 (TSF) and A99 (TLF showing a TSF profile). b. Profile of strains A201 (TLF) and A229 (TLF). *Sodium chloride gradient $0-100 \% \mathrm{M} \mathrm{NaCl}$. mulieris. These authors did not find any ALF, but Fox and Phillips (1984) reported that two of the 14 LF they studied hydrolysed hippurate and one hydrolysed arginine.

The possibility that the genus Mobiluncus could be divided into more than two species has been raised by several workers. Holst et al. (1982) grouped these organisms into three types, short, medium and long rods (considering the medium form as a subspecies of the long form) on the basis of cell morphology. DNA-DNA hybridisation studies (Christiansen et al., 1984) supported a subspecies of the SF, the LF yielding a more homogeneous group. Spiegel and Roberts (1984) also proposed the division of $M$. curtisi into two subspecies (M. curtisi ssp. curtisi and $M$. curtisi ssp. holmesi), but discrepancies between laboratories on several major criteria for distinguishing the species and subspecies cast doubt on the value of these proposals (Owen et al., 1984). Nevertheless, our results suggest that a categorical division of the organisms into just two species is unsatisfactory. The situation is complicated further by our finding that one strain that we identified as a TLF on the basis of biochemical tests and cell morphology had a cell protein profile by both SDS-PAGE and FPLC that was identical with that of a TSF. Baron et al. (1984) also described a LF possessing a major protein component of about $45,000 \mathrm{~mol}$. wt which is typical of a SF. It is clear that further studies are necessary to elucidate the problem of speciation and sub-speciation of these bacteria. 
The results reported in the literature for carbohydrate fermentations vary widely. Some workers have reported that all the strains were asaccharolytic (Holst et al., 1982), whereas others have reported different patterns of fermentation (Fox and Phillips, 1984; Påhlson et al., 1984; Taylor and Owen, 1984); our results are similar to those of Fox and Phillips (1984). Although the discrepancies may be due to different techniques, it is clear that the fermentation pattern is not a reliable criterion for differentiation of Mobiluncus spp.

The enzyme profiles also vary widely (Fox and Phillips, 1984; Hjelm et al., 1984; Taylor and Owen, 1984). The majority of the enzymic reactions were shared by all strains examined, in agreement with Christiansen et al. (1984) and Taylor and Owen (1984). However, we found the test for $\alpha$-galactosidase actively useful for distinguishing between TLF, which all gave negative results, and S.F., which generally gave positive results. The nitrate reduction test was suggested as a means of differentiating between the two groups (Baron et al., 1984; Taylor and Owen, 1984), but in our hands all strains gave positive results, irrespective of rod length, a result in agreement with that of Christiansen et al. (1984).

The antibiotic susceptibility patterns recorded by us are in agreement with those reported by other workers (Påhlson et al., 1984; Sprott et al., 1984) apart from metronidazole susceptibility. We did not find that metronidazole differentiated clearly between the SF and LF because some of the latter were resistant to it, a finding also of Jones et al. (1985). We also tested a new antibiotic, aztreonam (Squibb), to which all strains of Mobiluncus species were resistant at high concentrations (up to $50 \mu \mathrm{g} /$ $\mathrm{ml}$ ). This antibiotic is a new cephalosporin active mainly against gram-negative aerobes, and may,

\section{REFERENCES}

Baron E J, Wexler H M, Finegold S M 1984 Biochemical and polyacrylamide gel electrophoretic analyses of vaginosisassociated anaerobic curved rods. In: Mårdh P-A, TaylorRobinson D (eds) Bacterial vaginosis. Almquist and Wiskell, Stockholm, pp. 65-69.

Blackwell A L, Fox A R, Phillips I, Barlow D 1983 Anaerobic vaginosis (non-specific vaginitis): clinical, microbiological and therapeutic findings. Lancet 2: 1379-1382.

Borriello S P, Reed P J, Barclay F E 1985 Identification of bacteria by fast protein liquid chromatography. Journal of Medical Microbiology 19 : ix.

Borriello S P, Reed P J, Barclay F E 1986 The use of fast protein liquid chromatography for the identification of anaerobic bacteria. In: Borriello S P, Hardie J M (eds) Recent Advances in Anaerobic Microbiology. Martinus Nijhoff Publishers BV, The Hague, pp 292-294.

Christiansen G, Hansen E, Holst E, Christiansen C, Mårdh therefore, be useful in the development of a selective medium. The antibiogram of Mobiluncus strains is unusual for "gram-negative" micro-organisms, in that they are sensitive to vancomycin and bacitracin and resistant to colistin, like the majority of grampositive anaerobes. Of the gram-negative anaerobes only a few Bacteroides species, including members of the melaninogenicus-group, have been reported to have similar antibiotic susceptibilities (Sutter $e t$ al., 1980). It is noteworthy that Spiegel and Roberts (1984) had suggested that Mobiluncus organisms might belong within the family Bacteroidaceae. However, electronmicroscope studies of their cell wall structure (Fox and Phillips, 1984; Skarin et al., 1984) show that they do not have any outer membrane, as do gram-negative bacteria. Nevertheless, their cell wall structure does differ from typical gram-positive organisms and it is possible that Mobiluncus organisms are gram-positive bacteria that are easily de-stained, just as are eubacteria and some clostridia (Holdeman et al., 1977).

In conclusion, the taxonomy of the genus $\mathrm{Mobi}$ luncus is still unclear in that not all strains fulfil the criteria proposed for the two species and further studies will be needed to resolve this problem. Furthermore, as these organisms are fastidious, the development of an effective selective medium is necessary to clarify their pathogenic role in bacterial vaginosis and to establish the possibility of their sexual transmission.

We wish to thank the following for providing us with strains: Drs P.-A. Mårdh and E. Holst, Department of Medical Microbiology, University of Lund, Sweden; Drs U. Forsum and E. Hjelm, Department of Bacteriology, University of Uppsala, Sweden; Mr A. Fox, Department of Microbiology, St Thomas's Hospital Medical School, London and Mr A. Taylor, National Collection of Type Cultures, PHLS, Colindale, London.

P-A 1984 Genetic relationships of short and long anaerobic curved rods isolated from the vagina. In: Mårdh P-A, Taylor-Robinson D (eds) Bacterial vaginosis. Almqvist and Wilksell, Stockholm, pp. 75-78.

Cowan S T 1974 Cowan and Steel's Manual for the Identification of Medical Bacteria. 2nd edn. Cambridge University Press, Cambridge.

Durieux R, Dublanchet A 1980 Les "vibrions" anaérobies des leucorrhées I. Technique d'isolement et sensibilité aux antibiotiques. Médecine et Maladies Infectieuses 10: 109115.

Fox A, Phillips I 1984 Two curved rods in non-specific vaginitis. In: Mårdh P-A, Taylor-Robinson D (eds) Bacterial vaginosis. Almqvist and Wiskell, Stockholm, pp. 93-96.

Hjelm E, Forsum U, Hallén A, Påhlson C, Wallin J 1984 Primary isolation of curved rods from women with vaginal discharge. In: Mårdh P-A, Taylor-Robinson D (eds) Bacterial vaginosis. Almqvist and Wiskell, Stockholm, pp. 113-116. 
Holdeman L V, Cato E P, Moore W E C (eds) 1977 Anaerobe laboratory manual, 4th edn. Virginia Polytechnic Institute and State University, Blacksburg, VA, USA.

Holst E, Skarin A, Mårdh P-A 1982 Characteristics of anaerobic comma-shaped bacteria recovered from the female genital tract. European Journal of Clinical Microbiology 1 : 310-316.

Jones B. M, Geary I, Alawattegama A B, Kinghorn G R, Duerden B I 1985 In-vitro and in-vivo activity of metronidazole against Gardnerella vaginalis, Bacteroides spp. and Mobiluncus spp. in bacterial vaginosis. Journal of Antimicrobial Chemotherapy 16: 189-197.

Moi H. Danielsson D 1984 Studies on rabbit hyperimmune, patient and blood donor serum with regard to bactericidal activity and serum antibodies against anaerobic curved rods from patients with bacterial vaginosis. In: Mårdh PA, Taylor-Robinson D (eds) Bacterial vaginosis. Almqvist and Wiksell, Stockholm, pp. 87-91.

Nord C E et al. 1984 The diagnostic criteria for anaerobic curved rods. In: Mårdh P-A, Taylor-Robinson D (eds) Bacterial vaginosis. Almqvist and Wiksell, Stockholm, p. 262.

Owen $\mathrm{R}$ et al. 1984 Taxonomy of anaerobic curved rods. In: Mårdh P-A, Taylor-Robinson D (eds) Bacterial vaginosis. Almqvist and Wiskell, Stockholm, pp. 264-265.

Påhlson C, Bergqvist F, Forsum U 1984 Numerical taxonomy of motile anaerobic curved rods isolated from vaginal discharge. In: Mårdh P-A, Taylor-Robinson D (eds) Bacterial vaginosis. Almqvist and Wiksell, Stockholm, pp. 251-256.

Phillips I, Taylor E 1982 Anaerobic curved rods in vaginitis. Lancet 1: 221.

Skarin A, Mårdh P-A 1982 Comma-shaped bacteria associated with vaginitis. Lancet 1 : $342-343$.

Skarin A, Weibull C, Mårdh P-A 1984 Light and electron microscopic studies of anaerobic curved bacteria isolated from the vagina. In: Mårdh P-A, Taylor-Robinson D (eds) Bacterial vaginosis. Almqvist and Wiksell, Stockholm, pp. 59-64.
Spiegel C A, Amsel R, Eschenbach D, Schoenknecht F, Holmes K K 1980 Anaerobic bacteria in non-specific vaginitis. New England Journal of Medicine 303: 601-607.

Spiegel C. A. Eschenbach D A, Amsel R, Holmes K K 1983 Curved anaerobic bacteria in bacterial (nonspecific) vaginosis and their response to antimicrobial therapy. Journal of Infectious Diseases 148: 817-822.

Spiegel C A, Roberts M 1984 Mobiluncus gen. nov., Mobiluncus curtisii subspecies curtisii sp. nov., Mobiluncus curtisii subspecies holmesii subs nov. and Mobiluncus mulieris sp. nov., curved rods from the human vagina. International Journal of Systematic Bacteriology 34: 177-184.

Sprott M S, Pattman R S, Ingham H R, Short G R, Narang H K, Selkon J B 1982 Anaerobic curved rods in vaginitis. Lancet 1: 54.

Sprott M S et al. 1983 Characteristics of motile curved rods in vaginal secretions. Journal of Medical Microbiology 16: 175182.

Sprott M S, Ingham H R, Pattman R S, Clarkson L M, Codd A A, Narang H K 1984 Motile curved bacilli: isolation and investigation. In: Mårdh P-A, Taylor-Robinson D (eds) Bacterial vaginosis. Almqvist and Wiksell, Stockholm, pp. 107-111.

Sutter V L, Citron D M, Finegold S M (eds) 1980 Wadsworth anaeorobic bacteriology manual, 3rd edn. C. V. Mosby Company, St Louis, MO, U.S.A.

Taylor A J, Owen R J 1984 Morphological and chemical characteristics of anaerobic curved rod-shaped bacteria from the female genital tract. In: Mårdh P-A, TaylorRobinson D (eds) Bacterial vaginosis. Almqvist and Wiksell, Stockholm, pp. 97-106.

Thomason J L, Schreckenberger P C, LeBeau L J, Wilcoski L M, Spellacy W N 1984 A selective and differential agar for anaerobic comma-shaped bacteria recovered from patients having motile rods and non-specific vaginosis. In: Mårdh P-A, Taylor-Robinson D (eds) Bacterial vaginosis. Almqvist and Wiksell, Stockholm, pp. 125-128. 